\title{
Sekuritisasi Pandemi Covid-19 dan Tatanan Neoliberal: Menuju Deliberalisasi Ekonomi Global?
}

\author{
Januar Aditya Pratama, Yasmin Nur Habibah, dan \\ Teduh Gentar Alam \\ Universitas Padjadjaran
}

\begin{abstract}
Abstrak
Tulisan ini ditujukan untuk melihat potensi proteksionisme dan ketidaktergantungan negara-negara terhadap rantai ekonomi global di tengah wabah COVID-19. Sekuritisasi merupakan tindakan negara untuk meningkatkan status suatu isu menjadi ancaman eksistensial. Sesuai dengan logika teori sekuritisasi, penyebaran virus COVID-19 terus berkembang dan mengancam keamanan kesehatan. Oleh sebab itu, negara-negara melakukan tindakan sekuritisasi melalui penerapan kebijakan pembatasan perdagangan dalam industri medis yang sangat dibutuhkan pada masa pandemi. Tindakan sekuritisasi dilakukan oleh negaranegara yang suportif terhadap tatanan neoliberal global di era kontemporer. Dengan demikian, penulis akan menganalisis tindakan sekuritisasi melalui fokus studi kasus tiga negara yang mendukung tatanan neoliberal, yakni Inggris, Perancis, dan Amerika Serikat. Melalui sampel tersebut, penulis berhipotesis akan adanya kelemahan dalam sistem ekonomi liberal global yang menghasilkan ketergantungan rantai produksi dan distribusi antar negara dan berpotensi menimbulkan kerentanan terhadap pemutusan sepihak oleh beberapa negara dalam rantai produksi yang lebih memprioritaskan kepentingannya.
\end{abstract}

Kata kunci: Ekonomi Global; Neoliberalisme; Pandemi COVID-19; Sekuritisasi

This paper aims to find the potential trends of the protectionism of countries and their independence on global economic chains amidst of the COVID-19 outbreak. Securitization is a state action to increase the status of an issue into an existential threat. In accordance with the theory of securitization, as COVID-19 spreads and became a pandemic, it threatens the health security. Countries then take part in securitization efforts by limiting medical industry transactions, which products are urgently needed during the pandemic. Thus, the authors examines the acts of securitization from case studies of three countries that supports neoliberal order: Britain, France, and the United States. It is known that during the pandemic, countries in the world failed to maintain their liberal economic practices. Then, weaknesses are found in the global liberal economic system, where the dependency of the production and distribution chains can lead into vulnerability caused by unilateral termination from countries which prioritize their national interests.

Keywords: Global Economy; Neoliberalism; COVID-19 Pandemic; Securitization 


\section{Pendahuluan}

Pada akhir tahun 2019 lalu, dunia dikejutkan dengan berita akan epidemi virus Coronavirus (COVID-19) di Wuhan, Tiongkok, yang berujung pada penerapan kebijakan lockdown pada wilayah tersebut. Penerapan lockdown oleh pemerintah Tiongkok pada awal tahun 2020 mengakibatkan negara-negara lebih berhati-hati dalam berhubungan dengan Tiongkok. Dampak ekonomi yang ditimbulkan oleh isolasi Wuhan menyebabkan produksi dan distribusi komoditas lokal terganggu, hal ini turut diperparah dengan meluasnya penyebaran pandemi hingga ke seluruh wilayah Tiongkok sebagai negara eksportir terbesar di dunia (Investopedia 2018). Dinamika tersebut dipahami mengakibatkan rantai produksi dunia mengalami gangguan yang signifikan, terutama dalam kerangka interdependensi ekonomi global. Penyebaran COVID-19 yang semula merupakan situasi darurat kesehatan publik, turut berubah menjadi krisis ekonomi dunia bagi negara-negara besar dan mengancam negara-negara pinggiran (Lapavitsas 2020). Dengan peningkatan status tersebut mengakibatkan laju perdagangan komoditas terhambat dalam skala global.

Sebagai konsekuensi lanjutan, virus COVID-19 terus menyebar hingga ke negara-negara lain yang berakibat pada pelabelan COVID-19 sebagai pandemi oleh Organisasi Kesehatan Dunia (WHO). Setelah pelabelan sebagai pandemi, virus COVID-19 mulai dianggap sebagai ancaman serius terhadap keamanan kesehatan hampir bagi seluruh negara di dunia. Dengan jumlah korban yang terus bertambah setiap harinya, urgensi kebutuhan akan komoditas medis turut meningkat. Urgensi kebutuhan medis tersebut mengakibatan komoditas yang dibutuhkan seperti masker medis untuk wajah, ventilator, hingga obat-obatan mengalami keterbatasan suplai dan kurang mampu memenuhi permi ntaan yang melonjak drastis pada awal-awal di masa pandemi COVID-19.

Tiongkok, sebagai negara penghasil separuh total masker di dunia (Bradsher dan Alderman 2020), turut mengalami kesulitan dalam mengekspor kebutuhan masker dunia mengingat permintaan dalam negeri yang sangat tinggimenyesuaikan penderita infeksi COVID-19 di Tiongkok. Dengan fakta tersebut, negara-negara lain yang memiliki kapasitas untuk memproduksi komoditas terkait cenderung menempuh tindakan untuk membatasi arus suplai industrinya di mana produk yang dihasilkan hanya boleh digunakan secara domestik dan tidak untuk diekspor. Beberapa negara yang menerapkan kebijakan tersebut, ironisnya, adalah negara-negara yang sebelumnya menjadi pendukung pembebasan pasar global meliputi Inggris, Perancis, dan Amerika 
Serikat. Salah satu contoh dari komplikasi tersebut dapat dipahami melalui tindakan Amerika Serikat yang dituding melakukan praktik kotor dengan 'membajak' stok komoditas medis yang seharusnya dikirim untuk negara lain (Rajghatta 2020).

Solidaritas global dalam menghadapi pandemi COVID-19 dianggap memudar, di mana negara-negara yang tidak memiliki kekayaan yang sama dengan kekuatan-kekuatan besar mengalami kesulitan akses terhadap komoditas medis (al-Awsat 2020). Seperti halnya Italia, negara dengan kasus COVID-19 tertinggi di Eropa, tidak mendapatkan bantuan dari negara-negara Eropa lain. Ironisnya, justru Tiongkok yang mengirimkan tenaga medis, peralatan medis, dan obat-obatan kepada Italiayang mengakibatkan pemerintah dan rakyat Italia kecewa dengan Uni Eropa karena ketidakpedulian mereka terhadap negara anggotanya sendiri(Cherkaoui 2020). Dengan kesulitan pengadaan barang dan jasa medis yang terjadi di era pandemi, kebijakan neoliberal seperti outsourcing dan location economics mulai dipertanyakan (Marano 2020). Dengan pola ketergantungan ekonomi neoliberal yang berorientasi pada keuntungan membuat ekonomi global menjadi rapuh karena kesulitan mobilisasi barang dan jasa karena pandemi COVID-19. Prinsip-prinsip Neoliberalisme seperti Individualisme, deregulasi, dan desentralisasi menggerus pelayanan kesehatan publik bagi negara-negara yang melakukan reformasi neoliberal sebagai sebuah keniscayaan dan pengorbanan yang diperlukan (McGregor 2001, 82-83).

Dengan demikian, tujuan dari penelitian yang dilakukan bukan untuk menilai secara normatif tentang lunturnya nilai-nilai Liberalisme dalam ekonomi politik global saat pandemi sebagai sesuatu yang buruk atau tidak. Akan tetapi, tujuan penulis adalah untuk menunjukkan pola-pola bagaimana nilai Liberalisme dapat ditinggalkan oleh negara -negara di dunia dan bahkan oleh negara-negara pengusung kebebasan pasar itu sendiri. Sehingga, dapat ditemukan dampak dari tindakan-tindakan sekuritisasi, yang dasarnya bersifat realis, terhadap sistem internasional kontemporer yang didominasi oleh konsep neoliberal. Dengan teridentifikasinya dampak tersebut diharapkan dapat memberikan gambaran lebih luas akan bagaimana kelanjutan dari tatanan global pasca-COVID-19 baik dalam bentuk peningkatan interaksi yang kooperatif atau justru isolasionis.

\section{Perspektif Liberalisme Ekonomi}

Liberalisme ekonomi atau Neoliberalisme merupakan diskursus dominan yang diterapkan secara sistemik dan struktural dalam mekanisme kebijakan ekonomi politik global. Liberalisme ekonomi dibangun 
berdasarkan ide-ide liberal seperti kepercayaan akan kemajuan dan asumsi saling menguntungkan (positive sum game) dari perdagangan bebas tanpa eksklusivitas peran aktor negara. Dalam hal ini, pasar ekonomi adalah sumber utama kemajuan, kerja sama, dan kemakmuran. Sebagai paham yang bersifat progresif, Liberalisme - dalam konteks ekonomi mempertahankan otonomi individu dan melawan intervensi komunitas. Pola tersebut ditunjukkan melalui paham Neoliberalisme yang bersifat laissez-faire berasumsi bahwa perjuangan atas hak kepemilikan dan kebebasan individual dalam regulasi pasar dapat menyelesaikan masalah sosial (Chomsky dan McChesney 1999, 127; Jackson dan Sorensen 2015, 162).

Sistem Liberalisme ekonomi mengharuskan pemerintah untuk melakukan deregulasi dengan berbagai cara dan di sisi lain meningkatkan posisi aktor individu. Campur tangan politik dan regulasi negara terhadap pasar dipahami tidak efisien dan dapat menyebabkan konflik. Liberalisme ekonomi merupakan seperangkat prinsip untuk mengatur dan mengelola pertumbuhan ekonomi, dan kesejahteraan individu (Gilpin dan Gilpin 1987, 27). Hal ini didasarkan pada anggapan apabila ekonomi pasar dibiarkan berjalan secara spontan, maka operasi tersebut sesuai dengan mekanisme atau hukumnya sendiri. Salah satu contohnya adalah hukum keunggulan komparatif, yang diinisiasi oleh David Ricardo. Dia berpendapat bahwa perdagangan bebas akan membawa manfaat bagi semua aktor karena dapat memungkinkan spesialisasi yang mengarah pada peningkatan efisiensi dan produktivitas.

Aktor sentral dalam Liberalisme ekonomi adalah individu sebagai konsumen dan produsen. Pasar dipahami sebagai ekosistem tempat individu berkumpul untuk bertukar barang dan jasa. Individu-secara rasional-mengejar kepentingan ekonomi mereka sendiri untuk mendapat keuntungan. Namun, di sisi lain Liberalisme ekonomi sejak awal menyadari bahwa dalam beberapa kasus pasar mungkin tidak berfungsi sesuai dengan harapan efisiensi dan keuntungan bersama; kasus-kasus seperti itu biasanya disebut contoh 'kegagalan pasar'. Untuk menghindari hal tersebut, regulasi politik mungkin diperlukan untuk memperbaiki atau menghindari kegagalan pasar (Jackson dan Sorensen 2015, 164-167).

Dalam pembahasan Liberalisme ekonomi menurut Balaam dan Dillman (2015,9), terdapat kesenjangan yang meningkat antara pendekatan Orthodox Economic Liberals (OEL) yang memperjuangkan perdagangan bebas berprinsip monetaris dengan pendekatan Heterodox Interventionist Liberals (HIL) yang mendukung lebih banyak peraturan negara dan perlindungan perdagangan untuk mempertahankan pasar yang berprinsip keynesian. Pendekatan HIL menekankan bahwa pasar 
pasar bekerja paling baik ketika terhubung ke masyarakat dan negara melakukan intervensi untuk menyelesaikan masalah yang tidak bisa ditangani oleh pasar saja. Teori tersebut dipahami terbukti dalam kasus fenomena krisis finansial (Balaam dan Dillman 2015, 46-48). Berbeda dari pendekatan HIL, pendekatan OEL cenderung mencari kesalahan pemerintah ketika krisis terjadi dengan pengecualian terhadap kerugian dalam sektor individu yang tidak dapat diprediksi sedangkan HIL lebih memilih untuk mengalokasikan pengeluaran negara untuk mengatasi krisis selama tujuannya berorientasi pada kesejahteraan massal. Paham ini turut diterapkan pada lembaga-lembaga finansial internasional seperti World Trade Organization (WTO) dan melahirkan posibilitas negara maju untuk membantu negara berkembang.

Secara umum, Liberalisme ekonomi memiliki lima prinsip utama meliputi: (1) pemberian kebebasan dan keterbukaan perdagangan internasional serta investasi asing dengan meminimalisasi kontrol negara atas pasar; (2) memotong anggaran negara yang tidak produktif dengan memberikan subsidi besar-besaran pada perusahaan transnasional dalam bentuk tax benefit atau tax holidays; (3) regulasi ekonomi yang mengurangi segala bentuk regulasi Negara seperti pembentukkan Bank Sentral yang independen; (4) menjual semua perusahaan negara (seperti sektor perbankan dan industri strategis) untuk menghasilkan efisiensi dan menghindari korupsi; (5) menghilangkan gagasan barang publik dengan tanggung jawab individu di sektor-sektor ekonomi penting (Balaam dan Dillman 2015, 34-37; Chomsky dan McChesney 1999, 127-129). Setidaknya dapat disimpulkan bahwa baik liberal ortodoks maupun heterodoks pada akhirnya percaya bahwa Kapitalisme adalah sistem yang dapat dipertahankan, terlepas dari perbedaan cara kedua paham tersebut dalam mengusulkan reformasi globalisasi, mengatasi masalah utang, dan ketidaksetaraan. Dalam pengertian itu, kedua paham menempatkan keyakinan pada kemampuan pasar untuk mempromosikan nilai-nilai dan minat kebanyakan orang di dunia, sesuai prinsip dasar Neoliberalisme (Balaam dan Dillman 2015, 50).

\section{Teori Sekuritisasi dalam Hubungan Internasional}

Sebagai bagian dari gerakan pasca-positivis, sekuritisasi memiliki pendekatan yang berfokus pada proses yang mementingkan adanya konteks dalam analisis suatu isu. Dibawakan oleh Waever (1995) dan dikembangkan kembali oleh Buzan, et al. (1998), teori sekuritisasi masih berada dalam tradisi realis di mana negara dipandang sebagai aktor utama dalam Hubungan Internasional. Namun, sekuritisasi membawakan pergeseran paradigma pada studi keamanan menjadi turut mencakup isu-isu non-tradisional. Isu-isu tersebut dikategorisasi oleh menjadi lima 
sektor: militer, lingkungan, ekonomi, sosial, dan politik (Jorgensen, 2018, 185). Teori sekuritisasi menjelaskan tentang bagaimana proses penguasa suatu negara menindaklanjuti suatu ancaman yang sebelumnya kurang dianggap menjadi ancaman eksistensial melalui serangkaian tindakan sekuritisasi dan persuasi terhadap publik.

Pada dasarnya, teori sekuritisasi mencakup siapa yang melakukan sekuritisasi, isu apa yang disekuritisasi, untuk siapa atau apa, kenapa, dengan hasil apa, dan dalam kondisi apa (Buzan, et al. 1998, 32). Singkatnya, suatu isu baru menjadi isu keamanan apabila diidentifikasikan sebagai demikian (Taureck 2006, 54). Buzan, et al. $(1998,29)$ berargumen bahwa keamanan dapat dilihat sebagai kegagalan dari politik biasa. Mereka menjelaskan perspektif tersebut melalui spektrum isu-isu dengan asumsi bahwa suatu isu dapat bergeser dari spektrum tidak dipolitisasi, menjadi dipolitisasi, hingga disekuritisasi atau sebaliknya. Suatu isu yang telah masuk spektrum sekuritisasi dapat dicirikan dari bagaimana penanganan pemerintah, di mana suatu isu mendapatkan prioritas tinggi hingga pada tingkat melangkahi aturan konvensional yang berlaku.

Untuk memastikan koherensi analisis sekuritisasi, terdapat beberapa bagian dari tindak sekuritisasi yang harus dibahas, yakni isu yang dipersepsikan sebagai ancaman eksistensial, aktor sekuritisasi, objek referen, serta aktor fungsional. Ancaman eksistensial adalah sesuatu yang dapat melegitimasi pemerintah untuk mengambil suatu tindakan yang luar biasa (Roe 2008, 615). Suatu isu dapat dipersepsikan sebagai ancaman eksistensial melalui tindakan lisan dari politisi berkuasa di negara terkait. Hal ini mengakibatkan pembentukkan narasi ancaman eksistensial oleh para politisi sebagai ancaman yang dapat membuat negara menjadi irelevan dalam menangani isu-isu lainnya karena fungsi pemerintahan dapat terganggu oleh ancaman tersebut (Buzan, et al. 1998, 24).

Aktor sekuritisasi merupakan aktor yang mendeklarasikan suatu isu sebagai ancaman eksistensial. Aktor sekuritisasi tidak hanya mencakup kepala negara saja, tetapi parlemen hingga kelompok pelobi dapat menjadi aktor sekuritisasi selama hal yang disuarakan mendapatkan perhatian dan berpengaruh dalam agenda perumusan kebijakan. Untuk mencapai keberhasilan, aktor sekuritisasi harus mendapatkan dukungan formal dari segenap institusi pemerintahan yang terkait dengan isu yang akan disekuritisasi. dan dapat didukung oleh warga negaranya dalam dua bentuk: moral dan formal (Roe 2008, 620), yang turut menjadi penentu dalam keberhasilan tindak sekuritisasi.

Lalu, secara tradisional, objek referen dalam keamanan adalah negara 
atau bangsa (Buzan, et al. 1998, 36) dan dapat dikembangkan pada isu keamanan non-tradisional seperti keamanan ekonomi, lingkungan, sosial, dan politik. Tindakan sekuritisasi cenderung kerap dilakukan pada tingkat nasional, namun tingkatan unit objek referen untuk isu keamanan non-tradisional cenderung dominan pada tingkat masyarakat domestik. Terakhir, aktor fungsional merupakan aktor-aktor yang memengaruhi dinamika suatu sektor keamanan (Buzan, et al. 1998, 36). Pada suatu isu yang akan disekuritisasi, aktor fungsional memiliki posisi dominan dalam perumusan kebijakan pada sektor terkait hingga terjadinya tindak sekuritisasi. Akan tetapi, aktor fungsional tidak memiliki kapabilitas untuk membawa isu tersebut ke ranah politik meskipun memiliki kemampuan untuk memengaruhinya. Dalam hal ini, aktor fungsional tidak terbatas pada bagian dari pemerintahan saja, tetapi turut mencakup aktor non-negara.

\section{Metode Penelitian}

Penulis akan menggunakan metode kualitatif dalam penelitian ini. Menurut John W. Creswell dalam bukunya yang berjudul Research Design: Qualitative, Quantitative, and Mixed Methods Approaches (2014), penelitian kualitatif merupakan metode yang bersifat eksploratif yang mampu memahami peran aktor dalam studi kasus sosial humaniora. Hal ini kami lihat menjadi sebuah kecocokan bagi studi Ekonomi Politik Global untuk dianalisis menggunakan metode tersebut. Salah satu keuntungan menggunakan metode ini adalah hasil akhir penelitian yang jauh lebih fleksibel dengan sifatnya yang bergantung pada data. Metode ini memiliki cara yang bervariasi dalam melakukan pengumpulan data, baik data yang bersifat primer maupun sekunder. Salah satu karakteristik dari penelitian kualitatif yang ditulis Creswell adalah reflektivitas, yang mana merupakan kemampuan untuk meneliti kasus berdasarkan latar belakang dan fakta di lapangan.

Karakter ini memiliki potensi untuk membentuk interpretasi yang bersifat konstruktivistik, di mana aspek interpretasi dapat memajukan bias dan nilai-nilai dalam penelitian, tetapi turut mampu untuk membentuk arah penelitian (Creswell 2014, 233). Penelitian ini akan membahas mengenai bagaimana proses memudarnya nilai-nilai Neoliberalisme pada masa pandemi dengan menggunakan teori Neoliberalisme sebagai indikator utama. Merujuk pada empat tipe pengumpulan data menurut Creswell, salah satu yang dapat digunakan dalam penelitian adalah pengumpulan data sekunder dengan dokumen kualitatif yang dapat berupa dokumen publik (seperti koran, laporan resmi, dan sebagainya) maupun dokumen pribadi (seperti jurnal pribadi dan surat) (Creswell 2014, 239). Maka dari itu, untuk mendukung tujuan penelitian 
ini, penulis menggunakan studi literatur sebagai metode pengumpulan data untuk mengumpulkan fakta-fakta mengenai kebijakan-kebijakan nasionalis yang diambil negara-negara yang dihubungkan untuk menunjukkan pola-pola pergeseran sikap negara-negara dalam merespon pandemi COVID-19.

\section{Pembahasan}

\section{Tatanan Neoliberal Global}

Awal dari tatanan neoliberal global dapat dipahami dari periode awal pasca-Perang Dunia II (1945-1970) di mana pembangunan ekonomi cenderung berfokus pada negara sebagai aktor utama. Dinamika dalam era tersebut mulai membentuk traksi dalam isu pembangunan antara negara maju dan negara berkembang yang berujung pada gagasan bahwa perlunya keterlibatan komunitas internasional dalam proses pembangunan tatanan global. Dalam perkembangan ideologi ekonomi, pemahaman ini disebut dengan Liberalisme. Sistem pertama yang disiapkan untuk mendorong pertumbuhan dan pembangunan ekonomi global disebut dengan Sistem Bretton Woods. Sistem ini menyediakan peraturan yang mendorong keterbukaan akses dengan mengikat mata uang antar anggota secara lebih bebas dan difasilitasi melalui dua penggerak ekonomi utama dunia, yaitu Dana Moneter Internasional (IMF) dan Bank Dunia (Gilpin 2001, 310). Namun, paham Liberalisme tidak cukup untuk membentuk sistem perekonomian global yang mapan sehingga berujung pada perkembangan Neoliberalisme yang muncul di sekitar tahun 1970 hingga 1980.

Paham Neoliberalisme pada awalnya dikembangkan melalui konsensus yang terkesan dipaksakan. Agenda The New World Order mendorong pembentukan kesepakatan yang dikenal sebagai "The Neoliberal Washington Consensus" yang berisi sepuluh formula oleh John Williamson, ekonom asal Inggris, yang kemudian disebut Washington Consensus. Terdiri dari: (1) membahas mengenai disiplin fiskal di mana negara berkembang diminta menjaga anggarannya agar tetap surplus. Namun, apabila sisi fiskalnya tertekan atau mencapai batas minimum, hal itu dapat disebut sebagai defisit dan ditoleransi selama tidak melebihi 2\% dari Produk Domestik Bruto (PDB) negara tersebut; (2) belanja pemerintah sebaiknya diprioritaskan untuk memperbaiki distribusi pendapatan dengan rekomendasi pembiayaan proyekproyek dan program yang dapat menaikkan pendapatan kelompok menengah ke bawah; (3) sektor fiskal perlu direformasi melalui perluasan objek pajak dan wajib pajak; (4) sektor finansial perlu diliberalisasi; (5) penentuan kurs mata uang asing dan jaminan kredibel; (6) perdagangan 
sebaiknya diliberalisasi dan pemerintah harus menghapus batasan ekspor dan impor (barrier to entry and out) agar roda perekonomian berjalan secara efisien; (7) hendaknya investasi asing tidak didiskriminasi dan diperlakukan sama dengan investasi domestik karena keduanya diperlukan untuk mendorong perekonomian dan membuka lapangan pekerjaan; (8) BUMN sebaiknya diprivatisasi dengan tujuan efisiensi dan membantu pembiayaan defisit APBN; (9) melakukan deregulasi dengan menghilangkan berbagai bentuk restriksi sehingga pasar bersifat kompetitif; (10) pemerintah perlu menghormati dan melindungi hak cipta agar mendorong iklim inovatif dan kreatif di masyarakat. Iklim ini akan mendorong pembukaan lapangan pekerjaan dan kemandirian di tingkat masyarakat (Chomsky 1999, 47).

Sejak dikembangkannya Sistem Bretton Woods, tatanan dunia secara tidak langsung telah memihak dan didorong oleh kepentingan perusahaan transnasional (Transnational Corporations/TNCs) yang merupakan aktor penting dalam perekonomian yang kuat akan dependensi antar aktor. Selain TNCs, aktor lain yang memainkan peran besar dalam globalisasi adalah International Financial Institutions (IFIs) yang sering disebut sebagai Multilateral Development Banks. IFIs merupakan organisasi global yang beranggotakan negara maju dengan tujuan utama memberikan pinjaman kepada negara-negara berkembang, terutama negara yang cenderung miskin. Ada dua IFIs yang secara global dikenal yakni Bank Dunia dan IMF. Cara strategis untuk memaksakan berbagai agenda neoliberal tersebut adalah dengan menyertakan persyaratan pemberian pinjaman lembaga finansial internasional (Bank Dunia/IMF) yang dikenal dengan Structural Adjustment Program (Barnet dan Cavanagh 1995, 140). Dengan demikian, semua perubahan kebijakan yang dilakukan merupakan 'jalan pintas' untuk memudahkan perusahaan transnasional untuk beroperasi.

Lantas dalam kondisi pandemi ini, logika Neoliberalisme yang mendorong sistem pasar serta peran yang besar pada aktor-aktor swasta seharusya memberikan pemahaman bahwa sektor bisnis seharusnya berperan penting untuk membantu negara menghadapi pandemi. Namun, perlu dipahami bahwa dalam kondisi yang melihat rakyat sebagai prioritas utama berujung pada urgensi tindakan negara yang diperlukan dan cukup membawa kesulitan bagi paham Neoliberalisme untuk diterapkan secara rasional. Namun bagi beberapa negara, upaya Neoliberalisme ekonomi masih diupayakan. Salah satunya melalui contoh kasus permohonan Donald Trump kepada sektor bisnis untuk memulai kembali kegiatan ekonomi lebih cepat, serta seruannya kepada produsen mobil untuk memproduksi ventilator, merupakan sebuah keputusan yang konsisten 
melalui perspektif neoliberal (Naldoo 2020). Dalam hal ini, Trump berupaya untuk membuat fungsi pasar lebih dominan dan seminimal mungkin mengurangi peran negara dalam penanganannya. Tindakan tersebut dilakukan dengan asumsi bahwa sektor bisnis dapat menangani krisis yang dihadapi. Secara konsep, tindakan Trump merupakan implikasi bahwa memilih untuk tidak melakukan apapun adalah pilihan kebijakan.

Peran modal swasta, secara prinsip, dipandang sebagai tindakan amal. Sebagai contoh adalah sumbangan yang diberikan Johann Rupert dan Nicky Oppenheimer sebesar USD 125 juta kepada Dana Solidaritas Afrika Selatan. Bahkan jika kita memilih untuk melihat sumbangan ini sebagai cara pasar yang proaktif dalam menangani krisis, apakah tindakan semacam ini sudah efektif dalam konteks penanganan pandemi? Prinsip Liberalisme ekonomi atau yang kerap disebut sebagai Neoliberalisme mendukung upaya untuk meminimalisir aksi negara dengan membiarkannya ada mekanisme pasar. Perlu dipahami bahwa prinsip ini cenderung hanya mendukung pandangan moral yang menghargai kehidupan manusia dan menimbulkan solidaritas kolektif yang mana merupakan situasi yang cukup paradoksal saat ini.

Sekuritisasi Inggris, Perancis, dan Amerika Serikat terhadap Pandemi COVID-19

Sebagaimana bentuk sekuritisasi yang mana merupakan bentuk politisasi tingkat ekstrem, kebijakan-kebijakan negara Inggris, Perancis, dan Amerika Serikat menggambarkan kegagalan politik biasa dalam menghadapi masalah pandemi. Dalam menggambarkan kebijakankebijakan negara tersebut untuk melawan isu COVID-19 sebagai masalah keamanan kesehatan, usaha yang ditempuh dapat disebut sebagai tindakan sekuritisasi karena memberikan prioritas tinggi dan penanganan khusus terhadap suatu ancaman yang bersifat nonmiliter. Kegagalan politik biasa Inggris, Perancis, dan Amerika Serikat dalam menangani pandemi COVID-19 tergambarkan dalam bagaimana terjadinya peningkatan drastis dalam jumlah korban (Financial Times 2020). Hal ini mengakibatkan tindakan sekuritisasi terhadap isu pandemi dapat dibuktikan secara singkat dan jelas melalui kebijakankebijakan yang melampaui aturan konvensional liberalis ketiga negara tersebut.

Untuk kasus Inggris dan Perancis, kedua negara tersebut melarang ekspor terhadap obat-obatan yang penting untuk menangani penyakit yang timbul akibat COVID-19 (Rees 2020; France24 2020a). Perdana Menteri Inggris, Boris Johnson, menyatakan bahwa dengan masifnya 
penyebaran dan tingkat kematian akibat COVID-19 menjadikan momen dengan tingkat bahaya maksimum bagi Inggris (BBC 2020a). Kemudian, Johnson turut bertindak sesuai contoh tindak tutur (speech-act) sekuritisasi yang diutarakan oleh Buzan, Waever, dan de Wilde (1998, 24) dan menekankan bahwa seluruh aspek kehidupan Inggris akan terganggu secara parah, apabila isu pandemi COVID-19 tidak ditangani (UK Government 2020). Hal tersebut menghasilkan kebijakan yang nasionalistik, di mana Inggris melarang ekspor terhadap delapan puluh jenis obat-obatan demi menjaga suplai kebutuhan medis domestik (Buchan 2020).

Perancis dipahami tidak berbeda jauh dengan Inggris. Bahkan dengan statusnya sebagai anggota Uni Eropa, Perancis menolak himbauan Uni Eropa untuk menghapus pelarangan ekspor terhadap komoditaskomoditas medis dan justru meningkatkan jumlah obat-obatan yang dilarang untuk diekspor (France24 2020a). Sebagaimana yang diterangkan oleh Buzan, tindakan sekuritisasi Perancis turut diperkuat oleh tindak tutur dari Presiden Emmanuel Macron. Hal ini dibuktikan dengan pernyataan Macron bahwa kapabilitas Perancis kurang memadai untuk melawan pandemi, salah satunya diakibatkan oleh adanya kekurangan alat medis untuk melengkapi tenaga medis di Perancis (Ward 2020). Sesuai dengan prinsip sekuritisasi terhadap suatu isu, Macron mengatakan bahwa kehidupan di Perancis tidak akan sama seperti masa sebelum pandemi COVID-19 (France24 2020b). Hal ini ditekankan dengan kesadaran bahwa isu-isu lain akan menjadi irelevan apabila Perancis tidak menangani isu pandemi terlebih dahulu.

Sedangkan Amerika Serikat hanya melakukan pelarangan terhadap ekspor alat pelindung diri (APD) bagi tenaga medis. Meskipun hanya melakukan pelarangan ekspor terhadap komoditas tersebut, AS melakukan langkah yang merefleksikan tindak sekuritisasi melalui penggunaan Defense Production Act yang sebelumnya hanya digunakan pada Perang Korea dan Perang Dingin (Donnan et al. 2020). Hal ini dipahami menjadi esensi dari sekuritisasi, yakni membuat isu yang biasa saja termasuk ke dalam kategori ancaman non-militer dan menjadi prioritas bagi pemerintah untuk ditangani. Asumsi tersebut turut didukung dengan fakta bahwa jumlah kasus dan kematian akibat COVID-19 di AS merupakan yang tertinggi di dunia (BBC 2020b). Bahkan dalam usahanya untuk menangani besarnya ancaman akibat pandemi, AS turut menurunkan pasukan Garda Nasionalnya untuk menangani isu pandemi COVID-19 (Anders dan Bollettino 2020). Walaupun pada awalnya Presiden Trump cenderung berupaya mendesekuritisasi isu pandemi COVID-19, Donald Trump justru turut melakukan apa yang 
pemimpin dunia lain lakukan. Hal tersebut terbukti dengan tindak tutur Trump yang menyatakan bahwa tindakan pemerintah (dengan menetapkan status darurat nasional dan menerapkan Defense Production Act) adalah untuk menyelamatkan nyawa warga negara AS itu sendiri (White House 2020).

Melalui ketiga kasus tersebut, dapat ditemukan berbagai titik kesamaan dari tindak sekuritisasi yang dilakukan. Pola kesamaan tersebut setidaknya dapat diidentifikasi menjadi empat poin utama: (1) penyebaran virus COVID-19 tentu menjadi ancaman eksistensial karena sifatnya yang memiliki tingkat infektivitas yang tinggi serta menimbulkan dampak kesehatan yang fatal; (2) aktor sekuritisasi dalam penanganan isu pandemi COVID-19 adalah pemerintah yang turut mendapat dorongan dan tekanan dari pelobi, kelompok penekan, hingga masyarakatnya sendiri; (3) objek referen dari tindak sekuritisasi adalah nyawa dari para warga negara dan kelangsungan aktivitas ekonominya yang mana saling berkaitan dengan logika bahwa ekonomi tidak dapat berjalan apabila terlalu banyak masyarakat yang menjadi korban; (4) perusahaan produsen obat-obatan dan perlengkapan medis menjadi aktor fungsional dalam sektor keamanan kesehatan yang berkaitan dengan pandemi COVID-19 dan cenderung hampir tidak memiliki suara dalam perumusan kebijakan bagi sektor tersebut. Sekarang, negara secara tidak langsung mengambil alih operasi perusahaan-perusahaan tersebut untuk melayani kepentingan nasional semata yang mana berlawanan dengan nilai privatisasi Liberalisme ekonomi. Kemudian, negara-negara lain di dunia turut menerapkan pola Proteksionisme. Dengan demikian dapat dilihat adanya kekurangan dari kebijakan ekonomi liberal dan struktur Neoliberalisme global, yang pada tingkat tertentu diabaikan oleh negara-negara semasa pandemi. hal ini turut menunjukkan akan kelemahan tatanan neoliberal, di mana negara-negara penyokong sistem tersebut turut meninggalkan prinsip ekonomi liberal pada masa-masa darurat.

\section{Kemunduran Kecenderungan Neoliberalistik Akibat Sekuritisasi Pandemi COVID-19}

Pandemi COVID-19 menunjukkan berbagai kekurangan struktural dalam sistem Neoliberalisme pasca-Perang Dingin dengan akibat yang paling signifikan berupa ketidakstabilan alur ekonomi dalam sektor industri kesehatan serta ketergantungan satu sama lain untuk tetap siap menghadapi ancaman seperti pandemi (Lent 2020). Produksi peralatan medis dengan prinsip location economics di mana rangkaian produksi disebar di berbagai negara untuk menekan biaya produksi sehingga hampir seluruh perusahaan multinasional memiliki pabrik 
produksi awal di Tiongkok cenderung berdampak negatif dan berisiko dalam konteks pandemi. Dengan kebutuhan akan produk tersebut yang naik drastis di masa pandemi mengakibatkan dorongan untuk nasionalisasi dan pengembalian pabrik ke dalam negeri. Hal ini dapat dicontohkan dengan kasus di Tiongkok yang menahan produk masker untuk mereka sendiri, meskipun Tiongkok merupakan produsen masker terbesar di dunia dan negara-negara lain turut membutuhkan pasokan masker (Bradsher dan Alderman 2020). Kasus serupa dapat terlihat di AS, sebagaimana yang sebelumnya telah dibahas, di mana tren Nasionalisme ekonomi yang meningkat di tengah pandemi melalui retorika dan kebijakan Trump menunjukkan betapa mudahnya suatu negara yang menjunjung prinsip pasar bebas meninggalkan prinsip tersebut begitu saja (Palmer dan Heath 2020). Kebijakan proteksionis terhadap produk medis di tengah peningkatan secara drastis kebutuhan produk medis menunjukkan ketidakmampuan tatanan neoliberal untuk menyediakan sebuah kebutuhan dasar ketika dilanda krisis besar seperti pandemi. Hal ini cenderung menimbulkan pertanyaan apakah sistem neoliberal memang efektif sebagai sebuah sistem untuk menyetarakan kehidupan manusia? Atau keniscayaan yang disimbolkan melalui globalisasi ekonomi dan ideologi tak lain hanyalah sebuah propaganda aktor neoliberal yang mampu meraup keuntungan maksimal dari sebuah alur ekonomi dan hanya menyisakan sedikit kepada aktor lain?

Selanjutnya, penurunan tendensi Liberalisme ekonomi ditunjukkan melalui pembatasan masuknya barang serta individu ke dalam batas negara dalam kerangka tindak sekuritisasi yang dilakukan oleh aktor negara. Padahal, pada awalnya rantai pasokan panjang (supply chain) merupakan skema paling rasional yang digunakan untuk mengatur alur sirkulasi produksi global. Globalisasi neoliberal yang menekankan pasar bebas, minimalisasi peran negara, dan Individualisme cenderung bergantung pada rantai pasokan panjang global yang mudah terganggu oleh gangguan atau krisis berskala besar seperti pandemi (Borrell 2020). Globalisasi neoliberal bisa dipandang sebagai 'pelaku' karena kemudahan akses perjalanan sekaligus 'korban' penyebaran COVID-19 karena rantai pasokan global dan location economics serta interdependensi antarnegara dan antarkorporasi mengakibatkan penyimpanan di gudang dianggap berlebihan dan mendorong pasokan barang yang keluar-masuk hanya seperlunya (Farrell dan Newman 2020). Tidak hanya negara, bahkan para elit korporat turut menyuarakan kekecewaan mereka terhadap globalisasi karena kerapuhan struktur Neoliberalisme yang menopang globalisasi (Heer 2020). Pendapat senada disuarakan oleh Kinstler (2020) yang melihat bahwa pola-pola kebijakan negara-negara mirip satu sama lain bahkan dengan latar belakang 
yang berbeda menunjukkan bahwa dunia mulai kehilangan kepercayaan terhadap globalisasi dan meluasnya fenomena pasca-kebenaran turut berpengaruh kuat hingga ke tingkat pengambil kebijakan. Aktoraktor neoliberal yang selama ini menyuarakan gagasan pasar bebas dan orientasi pada keuntungan terhadap negara-negara nonliberal yang mayoritas negara-negara berkembang, akhirnya kehilangan kepercayaan pada paham yang menyokong mereka selama ini.

Lapavitsas (2020) melihat bahwa respons kebijakan yang lambat mendorong penyebaran COVID-19 yang semakin meluas sehingga kebijakan lockdown penuh terpaksa diterapkan dan membuat ekonomi yang sudah mulai melemah semakin memburuk dengan cepat akibat lenyapnya permintaan dalam skala besar, gangguan rantai pasokan, penurunan produksi, perumahan atau bahkan pemecatan jutaan tenaga kerja, dan penurunan pendapatan perusahaan. Pemulihan ekonomi turut menjadi sangat sulit di tengah kebutuhan sehari-hari yang masih harus terpenuhi. Beberapa jargon yang digaungkan oleh pemerintah dan aktoraktor neoliberal seperti "solidaritas", "komunitas", "tanggung jawab dan aksi kolektif" merupakan tanda bagaimana penyokong sistem neoliberal mulai beralih ke metode alternatif setelah tiga dekade menyuarakan pasar bebas, Individualisme, dan tanggung jawab individu (Peters 2020). Hal ini menandakan adanya spekulasi batas-batas nasional yang berpotensi akan menjadi lebih ketat terhadap industri dan pergerakan orang setelah akhir pandemi dibandingkan 30 tahun sebelumnya di era globalisasi sejak akhir Perang Dingin, dengan penarikan batas yang lebih tegas antara domestik dengan luar negeri dan penurunan kecenderungan dependensi pada hubungan internasional (Oba 2020). Krisis kesehatan dan ekonomi global yang terjadi merupakan dampak dari pilihan kebijakan yang diambil dari keengganan pemerintah dan institusi internasional (terutama institusi finansial seperti IMF) untuk mengambil langkah ameliorasi karena akan menguras sumber daya mereka yang ingin mereka pertahankan untuk diri mereka sendiri (Ghosh 2020).

\section{Ketidakpastian Masa Depan Tatanan Neoliberal Global Pasca-Pandemi}

Implikasi perusahaan multinasional dalam tatanan neoliberal global turut memerankan peran penting dibandingkan dengan negara, di mana negara memiliki keterbatasan dalam mengatur pergerakan aktor-aktor tersebut, tidak terkecuali dengan industri farmasi dan medis. Keterbatasan negara dalam menghadapi masalah tersebut adalah keterbatasan secara dogmatis dan turut secara legal, di mana banyak negara yang terikat dengan rezim perdagangan internasional. Chomsky (2020) berargumen bahwa sektor industri kesehatan tidak memiliki ketertarikan untuk mempersiapkan 
dunia dalam menghadapi pandemi-pandemi berikutnya. Hal tersebut diakibatkan oleh rasionalitas mereka yang berorientasi keuntungan, di mana persiapan jangka panjang tidak memberikan keuntungan bagi mereka. Bahkan, apabila pandemi terjadi, kejadian itu dapat dipandang sebagai suatu kesempatan untuk meningkatkan penjualannya. Sebagai contoh, sektor kesehatan di Amerika Serikat yang mengalami privatisasi justru diperkirakan tidak akan mampu memenuhi kebutuhan pelayanan kesehatan selama pandemi COVID-19 dan bahkan pengembangan vaksin COVID-19 diindikasikan tidak akan tersedia bagi semua kalangan karena adanya kepentingan kaum neoliberal untuk mencari keuntungan (Mohler 2020). Dengan demikian, karakteristik tatanan neoliberal dapat dipahami sebagai salah satu penyebab mengapa dunia cenderung tidak siap untuk menghadapi pandemi COVID-19.

Sistem neoliberal cenderung mendorong bencana kesehatan dan ekonomi. Hal ini dipahami diakibatkan karena penanganan oleh aktor-aktor neoliberal yang terlambat atau tidak tepat sasaran. NewsClickin (2020) dalam wawancaranya dengan Prof. Inderjeet Parmar, seorang ahli politik internasional University of London, berargumen bahwa terdapat beberapa jenis tendensi ideologi yang muncul selama masa pandemi COVID-19, dimulai dengan kemunculan kembali Proteksionisme nasionalis. Ia berpendapat bahwa sesungguhnya tidak ada kalangan manapun yang menyerukan Proteksionisme secara penuh, karena pada faktanya di lapangan, semua hal yang kita butuhkan selama kondisi pandemik (seperti makanan dan alat-alat kesehatan) merupakan bagian dari rantai suplai global. Ia mendukung pernyataan bahwa memutus rantai suplai global dan mengandalkan sumber daya internal secara penuh bukanlah solusi terbaik, karena ekonomi strategis akan selalu mengikat banyak aspek ekonomi. Namun dengan kondisi pandemi ini, yang terjadi pada level negara adalah sebaliknya, di mana negara memiliki kecenderungan untuk meningkatkan ketahanan nasional melalui diversifikasi ekonomi. Dengan kata lain, sistem dalam negeri ditingkatkan mobilitasnya agar setara dengan sistem internasional, bahkan dengan memanfaatkan berbagai sumber daya internal (NewsClickin 2020). Hal ini menunjukkan bahwa negara-negara tidak sepenuhnya memproteksi diri hingga menjadi isolasionis, tetapi mereka berupaya untuk mengurangi dependensi pada rantai produksi global untuk komoditas-komoditas yang dianggap penting dalam mengatasi ancaman eksistensial bagi negara.

Dari perilaku negara-negara dalam kasus respon pandemi COVID-19, pelemahan tatanan neoliberal kedepannya menjadi hal yang dapat terjadi. Negara-negara penyokong tatanan Neoliberalisme global, seperti Inggris, Perancis, dan Amerika Serikat cenderung beralih menuju 
kebijakan nasionalistik semasa pandemi. Hal tersebut tentunya akan merusak reputasi dan relevansi Liberalisme ekonomi, di mana hal tersebut tidak akan memberikan kepastian pada masa darurat. Perlu diingat bahwa reputasi merupakan sesuatu yang penting di dalam hubungan internasional (Wang 2006, 91). Setidaknya dapat dipahami bahwa terdapat keretakan hubungan dan kepercayaan antar negara yang diakibatkan dengan prioritisasi kepentingan nasional ketimbang solidaritas global dimasa pandemi. Hal ini berdampak dengan pola negara-negara untuk mengurangi dependensinya terhadap negara lain, terutama dalam hal komoditas-komoditas penting untuk menghadapi kondisi-kondisi darurat tertentu. Di sisi lain, Chomsky memperingatkan bahwa sikap otoriter dan represif beberapa negara justru dapat mendorong tatanan neoliberal menjadi lebih kuat karena pengaruh korporasi, terutama bidang energi dan manufaktur, terhadap pemerintah (Magdaleno 2020). Kebijakan neoliberal seperti privatisasi, terutama di sektor esensial seperti pangan dan kesehatan, mulai disuarakan untuk ditinggalkan. Akan tetapi, peninggalan kebijakan neoliberal menjadi sulit ketika elit korporasi merupakan rekan utama dalam rezim suatu negara, karena dorongan untuk nasionalisasi akan nasionalisasi akan selalu ditekan agar tidak terjadi (Nafi 2020). Nafi (2020) melanjutkan bahwa negara-negara maju dengan cadangan finansial yang besar dapat menutupi pengeluaran yang meningkat akibat pandemi, tetapi hal tersebut tidak berlaku bagi negara berkembang dengan ekonomi rapuh yang berujung pada ketidakmampuan dalam menangani krisis secara mandiri.

\section{Kesimpulan}

Melalui kasus Inggris, Perancis, dan Amerika Serikat-selaku negaranegara penyokong tatanan neoliberal global-dapat dilihat bahwa terdapat kesamaan dalam tindakan sekuritisasi terhadap pandemi COVID-19, di mana mereka membatasi hingga melarang ekspor komoditaskomoditas yang dianggap penting dalam menangani kondisi darurat. Tindak sekuritisasi yang mereka lakukan sesuai dengan asumsi bahwa tindak sekuritisasi dapat melangkahi norma dan nilai yang sebelumnya berlaku pada suatu negara. Hal ini dibuktikan melalui tindakan sekuritisasi terhadap pandemi yang berlawanan dengan prinsip Liberalisme ekonomi dan memiliki sifat yang serupa dengan kebijakan semasa perang oleh negara. Sekarang, negara cenderung mengambil langkah interventif yang lebih banyak jika dibandingkan dengan era sebelumnya dengan fakta bahwa korporasi-korporasi tidak memiliki kepentingan dalam menghindari kondisi darurat serupa 
dalam jangka panjang. Bahkan, pandemi turut dipandang sebagai kesempatan untuk mendulang keuntungan yang lebih banyak sesuai motivasi korporasi yang didorong oleh keuntungan.

Kemudian, melalui tindakan sekuritisasi oleh negara-negara untuk mengamankan situasi domestiknya, terjadi realisasi kerentanan dari sistem neoliberal yang ada. Ditunjukkan dengan dinamika rantai ekonomi global ketika salah satu unsur memutuskan untuk berhenti bekerja di dalamnya, maka akan terjadi kerusakan sistem secara menyeluruh. Hal tersebut terbukti dengan banyaknya negara yang membutuhkan peralatan dan perlengkapan medis untuk menangani pandemi di wilayahnya, tetapi terhalang oleh kebijakan yang cenderung proteksionis oleh negara-negara lainnya yang memproduksi komoditas terkait. Kebijakan-kebijakan tersebut disebut sebagai 'kecenderungan proteksionis', karena negara-negara tidak akan sepenuhnya menjadi isolasionis. Negara pada dasarnya berupaya untuk mengurangi dependensi pada rantai produksi global akan kebutuhan-kebutuhan vitalnya. Tren Proteksionisme tersebut turut berpotensi menimbulkan efek beruntun karena keterbatasan pasokan komoditas medis yang mengakibatkan urgensi pemenuhan komoditas melalui kebijakan proteksionis dan mendorong logika yang sama ke negara lain. Akan tetapi, patut diperhatikan bahwa untuk nasionalisasi ekonomi secara utuh merupakan suatu tindakan yang sulit untuk direalisasikan, mengingat adanya pengaruh korporasi dalam politik domestik masingmasing negara yang terlibat dalam tatanan neoliberal global. Dengan demikian, setelah Antagonisme semasa pandemi, kepercayaan terhadap sistem pasar menjadi pudar dan negara akan mengambil peran yang lebih besar di dalam ekonomi global. 


\section{Daftar Pustaka}

\section{Buku dan Bagian dari Buku}

Balaam, D., dan B. Dillman, 2015. Introduction to International Political Economy. Boston: Pearson.

Barnet, R., dan J. Cavanagh, 1995. Global Dream, Imperial Corporation and The New World Order: A Touchstone Book. New York: Simon and Shuster.

Buzan, B., O. Waever, dan J. de Wilde, 1998. Security: a New Framework for Analysis. London: Lynne Rienner Publishers.

Chomsky, N. dan R. McChesney, 1999. Profit Over People, Neoliberalism, and Global Order. New York: Seven Stories Press.

Creswell, J.W., 2014. Research Design: Qualitative, Quantitative, and Mixed Methods Approaches. California: SAGE Publications.

Gilpin, R., 2001. "The State and Economic Development", dalam Gilpin, Robert (ed.), 2001. Global Political Economy: Understanding the International Economic Order. New Jersey: Princeton University Press.

Gilpin, R., dan J. Gilpin, 1987. "Three Ideologies of Political Economy", dalam Gilpin, R., dan J. Gilpin (eds.), 1987. The Political Economy of International Relations. New Jersey: Princeton University Press.

Jackson, R. dan G. Sorensen, 2015. "International Political Economy: Classical Theories", dalam Jackson, R. dan G. Sorensen (eds.), 2015. Introduction to International Relations: Theories and Approaches. Oxford: Oxford University Press.

Jorgensen, K., 2018. International Relations Theory: a New Introduction. London: Palgrave Macmillan.

Waever, O., 1995. "Securitization and Desecuritization", dalam Lipschutz, Ronnie D. (ed.), 1995. On Security. New York: Columbia University Press.

\section{Artikel Jurnal}

McGregor, S., 2001. "Neoliberalism and Health Care", International (2):82-89. Journal of Consumer Studies, 25 (2):82-89. 
Peters, M. A., 2020. "The disorder of things: Quarantine unemployment, the decline of neoliberalism, and the Covid-19 lockdown crash", Educational Theory and Philosophy.

Roe, P., 2008. "Actor, Audience(s) and Emergency Measures: Securitization and the UK's Decision to Invade Iraq", Security Dialogue, 39 (6):615-635.

Taureck, R., 2006. "Securitization Theory and Securitization Studies", Journal of International Relations and Development, 9 (1):53-61.

Wang, J., 2006. "Managing National Reputation and International Relations in the Global Era: Public Diplomacy Revisited", Public Relations Review, 32 (2):91-96.

\section{Publikasi Daring}

Anders, B. dan V. Bollettino, 2020. "How the US Military Could Help Fight the Coronavirus Outbreak" [daring]. Tersedia dalam [https://gcn. com/articles/2020/04/27/how-military-could-help-fight-pandemic. aspx] (diakses pada [8 Mei 2020]).

al-Awsat, Asharq, 2020. "Scramble for Virus Supplies Strains Global Solidarity" [daring]. Tersedia dalam [https://aawsat.com/english/home/ article/2215106/scramble-virus-supplies-strains-global-solidarity] (diakses pada [24 April 2020]).

BBC, 2020a. "Coronavirus: Boris Johnson Says This is Moment of Maximum Risk" [daring]. Tersedia dalam [https://www.bbc.com/news/ uk-52439348] (diakses [4 Mei 2020]).

2020b. "Coronavirus Pandemic: Tracking the Global Outbreak" [daring]. Tersedia dalam [https://www.bbc.com/news/ world-51235105] (diakses [8 Mei 2020]).

Borrell, J., 2020. "The Post-Coronavirus World is Already Here" [daring]. Tersedia dalam [https://www.ecfr.eu/publications/summary/the post coronavirus world is already here] (diakses [19 Mei 2020]).

Bradsher, K., dan L. Alderman, 2020. "The World Needs Masks. China Makes Them, but Has Been Hoarding Them." [daring]. Tersedia dalam [https://www.nytimes.com/2020/03/13/business/masks-china-coronavirus.html] [diakses (4 April 2020].

Buchan, L., 2020. "Coronavirus: Exports of 80 Vital Drugs Banned by 
Ministers to Prevent NHS Shortages" [daring]. Tersedia dalam [https://www.independent.co.uk/news/uk/politics/coronavirus-uk-vaccine-drugs-exports-nhs-shortages-ban-a9414061.html] (diakses [4 Mei 2020]).

Cherkaoui, M., 2020. "The Shifting Geopolitics and The Demise of Neoliberalism (Part 1)" [daring]. Tersedia dalam [https://studies. aljazeera.net/en/reports/shifting-geopolitics-coronavirus-and-demise-neoliberalism-\%E2\%80\%93-part-1] (diakses [24 April 2020]).

Donnan, S., et al., 2020. “Trump Eases Covid-19 Export Ban Amid Backlash Around World" [daring]. Tersedia dalam [https://www.bloomberg. com/news/articles/2020-04-06/trump-s-covid-19-export-banprompts-backlash-around-the-world] (diakses [8 Mei 2020]).

Farrell, H. dan A. Newman, 2020. "Will the Coronavirus End Globalization as We Know It" [daring]. Tersedia dalam [https://www. foreignaffairs.com/articles/2020-03-16/will-coronavirus-end-globalization-we-know-it] (diakses [19 Mei 2020]).

Financial Times, 2020. "Coronavirus Tracked: the Latest Figures as Countries Fight to Contain the Pandemic" [daring]. Tersedia dalam [https://www.ft.com/coronavirus-latest] (diakses [4 Mei 2020]).

France24, 2020a. "France Ignores EU Calls to Lift Export Bans on COVID-19 Drugs" [daring]. Tersedia dalam [https://www.france24. com/en/20200423-france-ignores-eu-calls-to-lift-export-bans-oncovid-19-drugs] (diakses [4 Mei 2020]).

2020b. "In May Day Address, Macron Warns That Life Won't Return to 'Normal' After Lockdown Ends" [daring]. Tersedia dalam [https://www.france24.com/en/20200501-life-won-t-return-to-normal-after-lockdown-ends-macron-warns-in-may-day-address] (diakses [4 Mei 2020]).

Ghosh, J., 2020. "The Pandemic and the Global Economy" [daring]. Tersedia dalam [https://www.dissentmagazine.org/online articles/ the-pandemic-and-the-global-economy] (diakses [13 Mei 2020]).

Heer, J., 2020. "Thanks to Covid-19, Neoliberal Globalization Is Unraveling" [daring]. Tersedia dalam [https://www.thenation.com/cle/ world/globalization-unravelling-internationalism-coronavirus/] (diakses [13 Mei 2020]).

Investopedia, 2018. "What Country is the World's Largest Exporter of 
Goods?" [daring]. Tersedia dalam [https://www.investopedia.com/ ask/answers/011915/what-country-worlds-largest-exporter-goods. asp $\backslash$ ] (diakses [24 April 2020]).

Kinstler, L., 2020. “The US Coronavirus Response has Finally Shattered the Myth of American Exceptionalism" [daring]. Tersedia dalam [https:// www.businessinsider.sg/american-coronavirus-failures-global-response-2020-5? $\mathrm{r}=\mathrm{US} \& I R=\mathrm{T}]$ (diakses 13 [Mei 2020]).

Lapavitsas, C., 2020. "This Crisis Has Exposed the Absurdities of Neoliberalism, that Doesn't Mean It'll Destroy It" [daring]. Tersedia dalam [https://www.jacobinmag.com/2020/03/coronavirus-pandemic-great-recession-neoliberalism] (diakses [24 April 2020]).

Lent, J., 2020. "Coronavirus Spells the End of the Neoliberal Era. What's Next?” [daring]. Tersedia dalam [https://www.thebrokeronline. eu/coronavirus-spells-the-end-of-the-neoliberal-era-whats-next/] (diakses [11 Mei 2020]).

Magdaleno, C., 2020. "Chomsky on COVID-19: The Latest Massive Failure of Neoliberalism" [daring]. Tersedia dalam [https://www.euractiv. com/section/economy-jobs/interview/chomsky-on-covid-19-the-latest-massive-failure-of-neoliberalism/] ([diakses [16 Mei 2020]).

Marano, S. G., 2020. "Lessons from Coronavirus Pandemic Will Show That Our Economic Models are Deeply Flawed" [daring]. Tersedia dalam [https://www.scmp.com/comment/opinion/article/3077879/ lessons-coronavirus-pandemic-will-show-our-economic-models-are] (diakses [24 April 2020]).

Mohler, J., 2020. "Coronavirus Can Be a Death Blow to Neoliberalism If We Organize" [daring]. Tersedia dalam [https://www.jacobinmag. com/2020/03/coronavirus-health-care-neoliberalism] (diakses [1 Mei 2020]).

Nafi, B., 2020. "What Comes after the Pandemic?: Predicting the World to Come" [daring]. Tersedia dalam [https://studies.aljazeera.net/en/ policy-briefs/what-comes-after-pandemic-predicting-world-come] (diakses [16 Mei 2020]).

Oba, M., 2020. "Coronavirus and the Future of Globalization" [daring]. Tersedia dalam [https://thediplomat.com/2020/03/coronavirus-and-the-future-of-globalization/] (diakses [11 Mei 2020]).

Palmer, D. dan R. Heath, 2020. "How Trump is Using Coronavirus to 
Reshape World Trade" [daring]. Tersedia dalam [https://www.politico.com/news/2020/05/15/trump-coronavirus-world-trade-259814] (diakses 19 Mei 2020]).

Rajghatta, C., 2020. "Corona War Erupts as Germany, Canada Accuse US of Hijacking Supplies” [daring]. Tersedia dalam [https://timesofindia.indiatimes.com/world/us/corona-war-erupts-as-germany-canada-accuse-us-of-hijacking-supplies/articleshow/74985979.cms] (diakses [24 April 2020]).

Rees, V., 2020. "UK Bans Parallel Exporting of Crucial Medicines to Help COVID-19 Patients", [daring]. Tersedia dalam [https://www.europeanpharmaceuticalreview.com/news/115637/uk-bans-parallel-exporting-of-crucial-medicines-to-help-covid-19-patients/] (diakses [4 Mei 2020].

UK Government, 2020. "PM statement in Downing Street: 27 April 2020" [daring]. Tersedia dalam [https://www.gov.uk/government/speeches/pm-statement-in-downing-street-27-april-2020] (diakses [4 Mei 2020]).

Ward, A., 2020. "How President Emmanuel Macron Bungled France's Coronavirus Response" [daring]. Tersedia dalam [https://www.vox. com/2020/4/14/21218927/coronavirus-covid-france-macron-response] (diakses [4 Mei 2020].

White House, 2020. "Remarks by President Trump, Vice President Pence, and Members of the Coronavirus Task Force in Press Briefing" [daring]. Tersedia dalam [https://www.whitehouse.gov/briefings-statements/remarks-president-trump-vice-president-pence-memberscoronavirus-task-force-press-briefing-19/] (diakses [8 Mei 2020]).

\section{Lain-lain}

Chomsky, N., 2020. The World After Coronavirus: The Future of Neoliberalism - Part 1. [video daring]. Tersedia dalam [https://www.youtube. com/watch?v=20qQgQYBWvI\&feature $=$ emb logo] (diakses [15 Mei 2020]).

NewsClickin, 2020. COVID-19 and the Future of Neoliberalism. [video daring]. Tersedia dalam [https://www.youtube.com/watch?v=9XB-

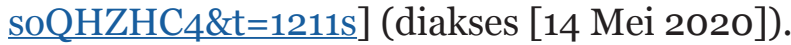

